\title{
SAINT NICHOLAS' BELEAGUERED BLACK COMPANION(S): A STUDY OF THE CONTESTED NATURE AND LATE ANTIQUE HISTORY OF SANTA'S HELPERS IN THE DUTCH SAINT NICHOLAS FEAST
}

\author{
L Müller, Research Fellow (Leiden University, $N L \&$ the University \\ of KwaZulu-Natal)
}

The Netherlands has a long history of celebrating Saint Nicholas Day. On the eve of the $5^{\text {th }}$ of December, the Dutch commemorate the date of death of the popular bishop from Myra, who protected citizens and sailors and gave his money to the poor. Bishop Nicholas, who came from a well-to-do Christian merchant family of Greek descent, lived in Asia Minor during the fourth century CE. Today, during the European winter months, a version of Saint Nicholas (Sinterklaas) features prominently in Dutch public spaces, especially in shopping malls and bakeries. Most often the saint is accompanied by one or more companions. This article explores the possible late antique origins of these companion(s), who have recently become embroiled in heated Saint Nicholas debates in the Netherlands on Dutch racism and the slave trade. I will posit that the Saint's current companion(s) have semi-historical origins which may be traced back to North African grain merchants, traders and sailors who in late antiquity regularly sailed from Alexandria to Myra. The proposal challenges contending theories that the Saint Nicholas legends did not have companions of African descent before the nineteenth century. The investigation is significant for questions relating to the current transformations in the appearance of Saint Nicholas' companion(s) and whether they should remain or rather be eliminated from the Dutch Saint Nicholas tradition.

Keywords: Saint Nicholas; Black Peter; Dutch folkloric history; grain trade; late antiquity.

\section{Introduction ${ }^{1}$}

Each year, in the winter months, Dutch children are spell-bound by the arrival, by steamship, of Saint Nicholas (Sinterklaas) and his Black Peters (Zwarte Pieten),

The author would like to thank the classicist Dr Cornelis van Tilburg and the Africanists Dr Meera Venkatachalam and Dr Laura Mann for their valuable comments on this article. 
a public event that marks the beginning of the Dutch Saint Nicholas feast (Figs. $1 \& 2$ below).

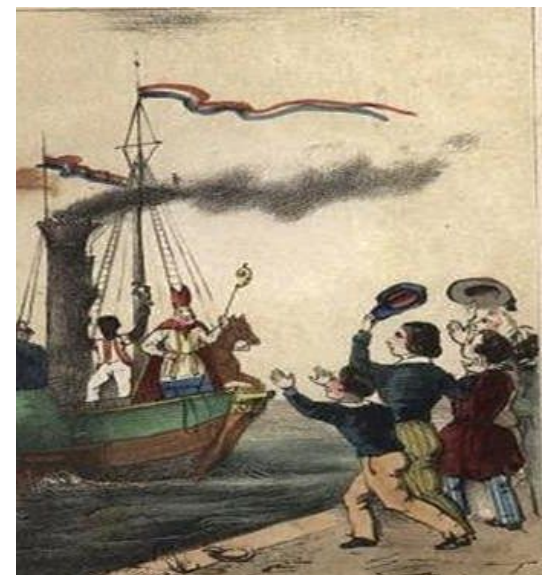

Fig. 1: Arrival of Sinterklaas from Spain (Schenkman 1850:2).

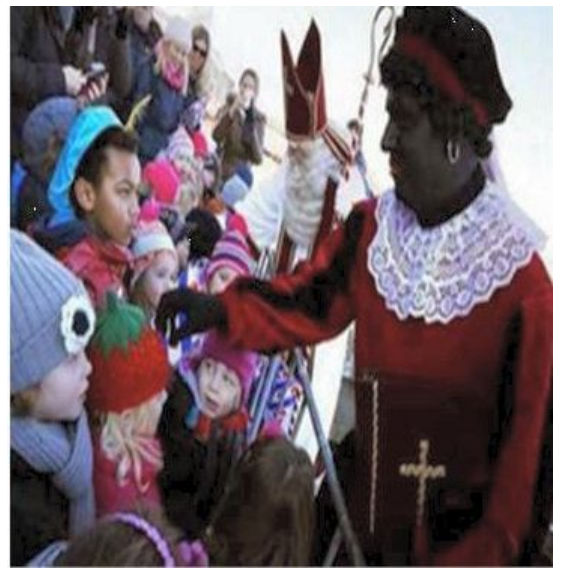

Fig. 2: Dutch celebration of Sinterklaas (Müller 22 October 2013:1). Photo Public domain.

These public commemorations were recently subjected to criticism on an international podium. In 2013, a national debate on the nature and origin of the companion(s) of Sinterklaas, going back to the 1920s, received international attention through Verena Shepherd, a Caribbean-born professor and chairwoman of a working group that functions as an advisory board of the United Nations (UN), and consists of independent experts on the rights of people of African descent. During a Dutch television interview, Shepherd announced that her team would investigate whether or not the Dutch Sinterklaas feast was racist and should be abolished, concluding pre-emptively that the Dutch feast was 'a throwback to slavery' as in colonial times (NOS Nieuws 2013). The broadcast caused heightened emotions in the Netherlands, resulting in demonstrations for and against the celebration of Sinterklaas that includes his companion(s). Arguments related mainly to the nature and the origin of the saint's companion, since 1895 is known as Black Peter. ${ }^{2}$ Those who advocated for a Sinterklaas feast without Black Peter(s) regarded the figure as a stereotypically portrayed ethnic African, whose invention

2 Initially, the Saint's black companion was nameless. In 1884 the Catholic writer Jozef Albert Alberdingk Thijm gave him the name Pieter-mê-knecht (Peter my servant). In 1895, this name was standardised as Black Peter. $C f$. Helsloot 2011: section 'Jozef Alberdingk Thijm'. 
coincided with the abolition of the slave trade in the Netherlands. His inventor was supposed to be the Dutch schoolmaster Jan Schenkman (1806-1863), the author of the 1850 publication Sint Nikolaas en zijn knecht [Saint Nicholas and his servant], an illustrated children's book on Sinterklaas. In the initial edition, Sinterklaas appeared without any companion, but he was in later editions accompanied by several black helpers. ${ }^{3}$ During the period 1840-1880, demeaning depictions of black people spread from the American South through, among others, the performance of minstrel shows. These were performed in the southern states after the abolition of slavery as a racist strategy to culturally denigrate and demonise black Americans, to counter the abolition movement and black emancipation, and to sabotage their integration as equal citizens in the American society (Putseys 2015:2-3; Cockrell 1997:140-63). Such demeaning depictions also reached European centres during this time, and a parallel development may be seen after the official abolition of slavery in July 1863 in the Dutch plantation colony of Surinam. The argument goes that the change between editions of Schenkman's book bear witness to the American influence on Dutch children's literature.

Those against the removal of Black Peter(s) from the festivities have pointed to substantial evidence of Saint Nicholas accompanied by a figure, or figures, long before Schenkman's book. Some argue for the companions to be mythical figures unrelated to their depiction as ethnic Africans. To some, the Dutch Saint Nicholas celebration is rooted in Pre-Christian Indo-European shamanistic hunting and fertility rites, during which the participants blackened their faces to invoke and then represent spirits; Saint Nicholas is thus seen as a successor of hunting goddesses such as Artemis/Diana or even more ancient, and his companions as displaying their characteristics as remnants of the inculturation of Christianity in late antique Myra. In support of this theory, it is mentioned that Myra, where Nicholas became the metropolitan bishop, indeed had a temple dedicated to Artemis Eleuthera, and that Bishop Nicholas was instrumental in the demise of her cult (Blom 1998:228-229). Adherents of this theory seem to deny that the Dutch slave trade could have influenced the appearance of the saint's companion (Scheer 2014:20-24).

In contrast, this article explores possible late antique roots of Saint Nicholas' companion(s) from a different angle, namely that the Dutch Saint Nicholas and his Black Peter(s) came to be modelled on real historical interactions between the metropolitan bishop of Myra and grain traders, merchants and sailors from North Africa who frequented the late antique city.

In the 1850-1905 editions of Schenkman's Sinterklaas book, the Saint has only one black companion. In the 1907 edition of this book, however, there is a picture of Sinterklaas assisted by five black helpers: Schenkman 1907:17. 


\section{On the late antique roots of Saint Nicholas' companion(s)}

To consider the pre-nineteenth century existence of Saint Nicholas' North African companion(s), it has to be acknowledged that the veneration of the saint has an international history - the Saint Nicholas legends did not originate on Dutch soil but go back to late antiquity. The question is, therefore, if it can be shown that North Africans had a presence in the Myra of the historical Bishop Nicholas, and whether they occur in the earliest Saint Nicholas legends on record, namely from the ninth century CE.

Throughout the late antique Roman period, Alexandria remained Egypt's most important city. The elite of this culturally Greek-oriented city maintained connections with the intellectuals and philosophers of Athens, Rome and Byzantium. Late antiquity saw the growth of Christianity in North Africa, Asia Minor and Europe. By the 320s CE, nearly half of the population of Roman Egypt was Christian. Myra, a near-coastal city on the pilgrim's way to Jerusalem, also had a growing Christian community though the Christians were still a religious minority and some in Lycia, the province of which Myra was the Metropolitan city, requested imperial sanctions against them. The bishop of Olympos in Lycia, Methodius, was allegedly put to death in the last year of the Diocletianic persecution. It seems from later sources that the Christian teachings in Myra were in line with orthodoxy, though Bishop Nicholas himself did not seem to have played a large role in defining this direction. According to a fourteenth-century vita, the bishop of Myra was present in $325 \mathrm{CE}$ at the Council of Nicaea's christological debates on the nature of Jesus as entirely divine or partly human, where he defended the orthodox Christian opinion on the divinity of Jesus, and even physically attacked his opponent Arius (Harrison 1963:118-120, Akyürek 2016:469-471, Ruffini 2018:3-5). However, it seems more likely that his name was only added in later copies of the bishop attendance lists because on the list transmitted as original, the only signatory from Lycia was the Bishop Eudemus of the city of Patara (Anrich 1917:17, 301).

Besides the cultural, philosophical and religious links between the cities of Myra and Alexandria, they were also connected through Roman's imperial intercontinental trade. Alexandria played a key role in this trade of which the transportation of grain was most prominent. Until the sixth century CE, Egypt was perceived to be the breadbasket of the Roman Empire and grain was transported by boats that sailed the Nile. In various coastal cities near the Nile, grain was stored in granaries that were emptied by grain merchants anchoring at these towns. In Alexandria, some of the grain was distributed to the poor, including widows and orphans, by Bishop Athanasius and other non-Arian church officials. However, a large part of the grain surplus was transported to other Roman urban areas to feed 
the poor, such as Rome and Byzantium. The grain trade was of enormous proportions. Until Rome ceased to be the capital of the Roman Empire, the socalled caput mundi (Carlà-Uhink 2017:119), the city received around 83,000 tons of grain from Egypt per year. Since the 320s CE, when Constantinople became the Empire's capital, 220,000 tons of grain were annually transported there from Alexandria. This means that during the lifetime of Bishop Nicholas, around 647 average-sized grain ships sailed from Alexandria's harbours each year; in the sailing season of approximately four and a half months, over 32 fully loaded vessels sailed weekly from Alexandria (Haas 2006:42).

The city of Myra was located near the harbour town Andriake, which was an important transit point in this grain trade from Alexandria to Rome and Constantinople (Akyürek 2016:465-468). The grain trade was very important for the citizens of the Roman Empire because many of its urban areas were not selfsufficient and were dependent on the supply of grain from Egypt and other parts of Africa (such as Carthage in contemporary Tunisia). Especially in times of famine, the Romans depended on the supply of grain to their cities. For the grain merchants, the trade and distribution of grain was an economic activity and not an act of philanthropy. The fact of the matter is that non-Arian Christians, including Bishop Nicholas, provided the finances necessary to allow the grain traders to make part of their cargo freely available for the poor. For the churches, the distribution of grain was a form of charity, which was an important virtue in Christianity at the time and still is today ( $c f$. Blom 1998:164-176).

The cities along the trade network were hubs that provided trade links with Europe (as far as Britain), Asia Minor, Syria, Arabia, India and even China (Young 2003:51-54). The traders that lived in these hubs often came from elsewhere and formed diaspora trade communities. It is therefore unsurprising that Alexandrian and other merchants formed a diaspora community in Myra and vice versa. It is known that, after his death, the liturgy for Bishop Nicholas was attended by foreign seafarers and that there were Egyptian shipping companies in Myra (Blom 1998:47-48). Conversely, the city of Alexandria contained communal enclaves, such as Lycians and Phrygians (Blom 1998:35-38, Haas 2006:49-50). Also in Byzantium/Constantinople one could find a diaspora community of merchants and seafarers, who came, among other places, from Asia Minor and North Africa. One of the largest groups among these relatively independent migrant communities consisted of the men of the Alexandrian imperial grain fleet. These seamen, who admittedly lived in Constantinople but remained cultural outsiders, preserved a maritime subculture and were often distinct from the local Christian population in terms of morals, practices and beliefs (Wade 2014:271-274). For the Byzantines the association of Egypt with the grain trade was so strong that they believed the stories of Christian pilgrims who had reported that the province of Egypt was full 
of enormous triangular grain silos, known as Joseph granaries (see Fig. 3 below), which today are known as the pyramids of Giza (Wilkenson 1981:204). ${ }^{4}$

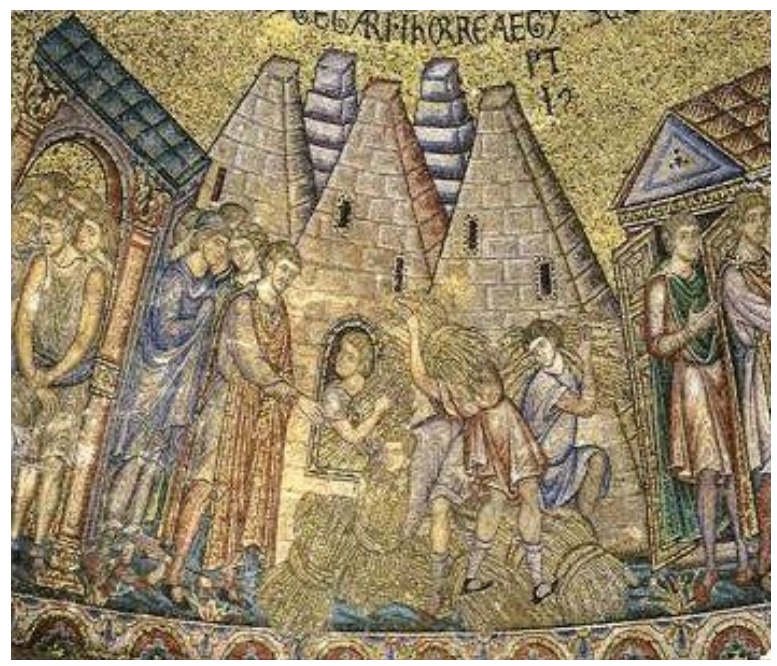

Fig. 3: Mosaic of Joseph gathering corn. San Marco,

Venice, ca. 1275.

The inhabitants of Constantinople were also not surprised that the Egyptians among them venerated the Kushite-Egyptian god Serapis, whom the Christians transformed into Joseph, and the goddess Isis, whom the Christians knew as Mary. Isis was the patron goddess of sea grain merchants and sailors, helping them to survive heavy storms and guiding them safely to the harbour. Isis and her husband Osiris were also strongly associated with bread and the grain of which it is made (Parry 2014:182-185, Wade 2014:277-281).

On the island Antirhodos in the city of Alexandria's eastern harbour (Portus Magnus) stood an Isis temple. From there, the goddess watched over the large grain vessels that were used to sail the Mediterranean via Cyprus and Myra to feed the inhabitants of large urban areas of the Roman empire (Young 2003:31-33, 4648, Butler 2007:193).

What do we further know about the belief of the sea merchants, shipowners and sailors who were involved in this trade? Greek and Roman literature, which often mentions the large Alexandrian ships, clarifies that the Egyptian grain ships'

4 According to Genesis 41, Joseph oversaw the storage of grain in Egypt during the years of plenty so when famine had spread over all the land, he could open all the grain silos. 
crew members, who formed the majority of the crew of all ships involved in the intercontinental grain trade, were usually multireligious. Among them were both Christians and venerators of the Roman-Greek and Egyptian-Kushite pagan gods. A ship named after Isis was believed to contain the caring spirit of Isis herself (Brody 2008:448-451, Wade 2014:271-274). The second century CE Lucian wrote a partial description of an ancient ship called the Isis, a huge grain vessel that he observed in the harbour in Piraeus near Athens. In his dialogue The ship, or the wishes, Samippus, an Arcadian landlubber remarks that the Isis was said to carry enough corn to feed all Attica for a year (Navigium 6). Depictions of Isis, who in Egyptian-Kushite mythology braves the waves to find her husband Osiris, were visible on either side of the ship. During the second and third centuries the veneration of Isis and Serapis was widespread in Asia Minor. They were important competitors with Christianity, in particular, it seems, in harbour cities where the grain merchants stayed. ${ }^{5}$ From $376-377$ CE the Roman emperors restored a temple of Isis at the port of Ostia. This was done under supervision of Sempronius Faustus, prefect of the grain supply to Rome. ${ }^{6}$ Isis was said to protect the crew of the grain fleets entering Rome (Witt 1971:180, Vidman [1969] 2011:VS 562). In Byzantium, Isis Pelagia (Isis of the Sea) was so important to the many crew members of the grain fleets that they were reluctant to give up their belief well into the sixth century (Wade 2014:277-281).

Celebrations in honour of the goddess Isis were held by Egyptian and Roman mariners onshore to mark the beginning of the sailing season on the Mediterranean, to ask for protection before setting sail and to thank her after a safe landing in harbour towns. In the surroundings of Andriake, the harbour town near Myra, many grain vessels shipwrecked due to heavy storms (Foss 2002:132142, Tomorad 2005:247-248, Leidwanger 2007:311-312). This might explain the popularity of Isis in this town and of Saint Nicholas in Myra. ${ }^{7}$ Isis and Osiris were the ancestors of the feather-headed Egyptian-Kushite goddess Ma'at, who represented the principle of justice in Greater Egyptian culture (Budge 1967:cxix).

Excavations in Andriake next to Myra and those in Puteoli and Ostia near Rome prove that this goddess and Serapis were popular and frequently venerated; $c f$. Magie 1953:163-166, Johnson 1958:12, Tomorad 2005:245-248, Brody 2008:446-450.

6 An inscription on the architrave of this temple excavated at Ostia Antica names the Roman emperors Valens, Gratian and Valentinian, as well as the supervisor Faustus, as the restorers of this temple of Isis. $C f$. Keay \& Boetto 2010:11-23.

7 The journey from Alexandria to Constantinople was dangerous for seamen, because for large parts of the journey the coast was out of sight, therefore, there was a great risk of shipwreck; see Hordon \& Purcel 2000:127 Map 9, 'Areas from where you cannot see the coast'. 


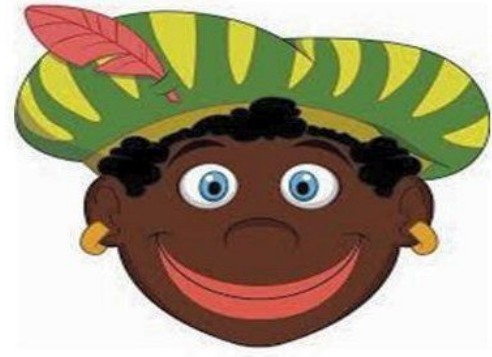

Fig. 4: Black Peter with an ostrich feather in commercials.
Since Pharaonic times, many of the North African sea merchants wore a beret with an ostrich feather in honour of this goddess which resembles that of the Dutch Saint Nicholas' companion(s) in later depictions (see Fig. 4 to the left and Fig. 5 below). Considering the vested interests in the Isis cult of the merchants and crews of the grain fleets, it may be asked what attraction the figure of the Christian Orthodox bishop held for these people. Could it be that Bishop Nicholas was comparable to the Isis-Osiris pair? To answer this question, the next section will dwell upon what can be known of the life of Bishop Nicholas from the early Saint Nicholas legends, and how that may relate to the Alexandrian grain merchants and sailors that frequented the vicinity of Myra.

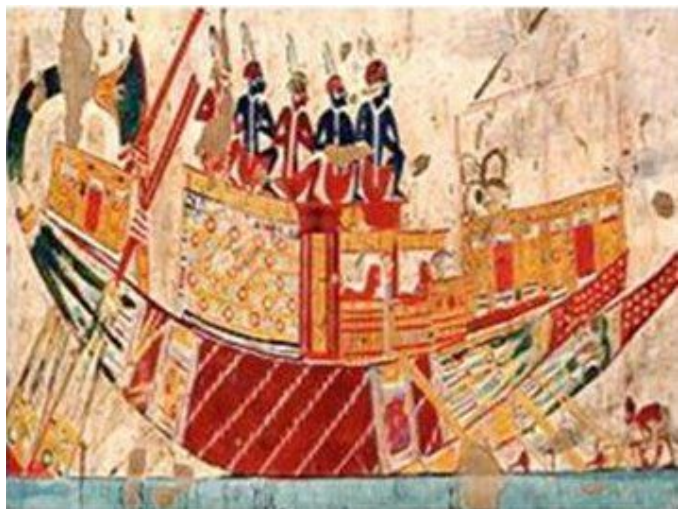

Fig 5: A vessel with North Africans, New Kingdom, ca. 1353-1327 BCE, tempera on paper Upper Egypt, Thebes. Public domain.

Nicholas, whose parents according to tradition were devout Christians, was born in 270 CE in Patara, a flourishing maritime and commercial city on the south-west coast of Lycia. His parents were well off, possibly from mercantile activities, and they were frequently involved in charity work among the poor. After his parents passed away, the young Nicholas became a priest and surrendered his life and possessions to the Lord. One legend tells of the occasion when he distributed a sack with gold coins to a poor man to provide dowries for his three daughters (Quinn and Sewell 2014:3.9-13, 22, 23). After his death around the year $363 \mathrm{CE}$, he became the patron of sea merchants and sailors, and was believed to perform miracles to help sailors and the poor and hungry in times of need. Already in late antiquity a body of traditions existed about Saint Nicholas the benefactor of the very poor and needy. Unlike the pagan Romans, the 
Christians were involved in charitas, including organizing the free distribution of grain to such groups.

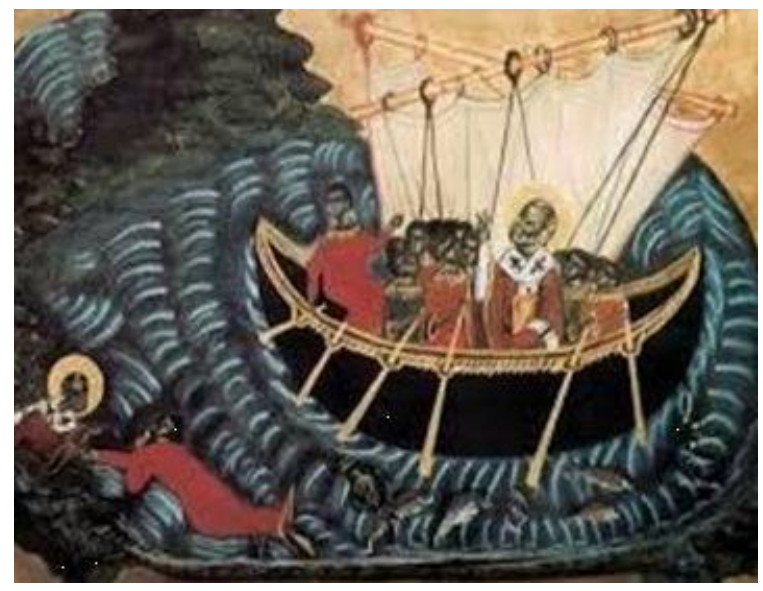

Fig. 6: Saint Nicholas as the patron of the black African sea merchants, who he saves from drowning. Source: Centro Studio Nicolaiani. The figure is of Medieval origin, exact year unknown. Public domain.

Unsurprisingly, in the Vita per Michaelem, a $9^{\text {th }}$ century document which is the earliest surviving source and the first complete biography on the life of the saint, Nicholas was praised as the father of orphans and the helper of those in danger and need. In 'the miracle of the saving of the mariners', Saint Nicholas helps a group of seamen who were the victims of a demon and were almost shipwrecked, to reach a safe harbour (see Fig. 6 above). When the seamen went to a church to thank the saint for his miracle, he answered them that they should behave well and free themselves from sins so that next time God himself would come to save them (Quinn and Sewell 2014:30, 34-36). ${ }^{8}$ Saint Nicholas thus figured as an assistant of God and an active proselytizer of sailors.

Another Saint Nicholas legend in the Vita per Michaelem is 'the miracle of the grain'. Possibly going back to the year $311 \mathrm{CE}$, it tells of how Bishop Nicholas asked the captain and crew of a fleet of grain ships from Alexandria in the harbour of Myra (Andriake) for a hundred hogsheads of corn from each ship to help feed the population of his town. The city of Myra suffered from famine as a result of crop failure. At first, the sailors, the merchants and their captain hesitated because

8 Earlier partial accounts had been written on Saint Nicholas' life but no complete biography. Michael drew on earlier written sources and oral tradition. 
their load was meant for the Roman emperor in Byzantium, and rumours had it that whoever brought less grain to the emperor than agreed upon, were tortured and imprisoned. Bishop Nicholas guaranteed them that their cargo would remain as when they received it in Alexandria. As promised, when the grain load arrived in Byzantium, it was unaffected by the distribution of grain to the poor and needy citizens of Myra. The sailors thanked their bishop and praised God, while Myra had enough grain to feed the population for the next two years and to plant their crops in the following year (Quinn and Sewell 2014:37-39).

So, was Saint Nicolas a plausible substitute for Isis and Osiris once Christianity gained more ground in the Byzantine Empire and the Egyptian pagan gods were demonised? In Egyptian mythology, Isis often acted as a servant of the goddess Ma'at, who represented justice and was responsible for order in the universe. She restored order by gathering the pieces of her brother-husband Osiris from the bottom of the Nile and by resurrecting him from death after which he remained in the underworld (the duat) as ruler and judge. With this act, she reversed the chaos in the universe created by their brother Seth, who out of jealousy had killed his more popular brother by chopping his body into pieces and throwing it into the Nile (Plutarch, Isis and Osiris 18). By resurrecting Osiris, Isis - who was also a fertility and vegetation goddess - had simulated the cycle of the crops and the regeneration of nature (Griffiths 1980:163-171). As the personification of the archetypal feminine principle and as wife, she also helped Osiris with his process of individuation by healing him as she assembled the pieces of his dismembered body and melt them together into a whole (Cavalli 2016:65$69)$.

In the two mentioned Saint Nicholas legends that focus on mariners, the saint appears from the beyond to help people in need by rescuing them or by providing financial assistance. In the 'miracle of the grain' the saint acts like a Christianized Isis to restore the order in the universe by expelling a demon (instead of Seth) and restoring the grain harvest in Myra. Also the Egyptian-Roman Serapis seems to be reflected in the Saint Nicholas legend. Serapis was a composite god, combining Apis and Osiris, created to represent the Ptolemies in Egypt. He was also a grain god who ensured that the grain was measured correctly (Auffarth 2014:26-30). In the legend of the grain miracle, Saint Nicholas - like Serapis ensured that, once the sea merchants would enter the harbour of Constantinople, their grain load was not diminished either quantitatively or qualitatively. The protection of such overseer gods, either pagan or Christian, at the beginning and the end of their journeys, was important for these merchants, as any problems with their cargo could cause severe economic loss.

Under the feet of Serapis lies the dog Cerberus, who, like Osiris, guards the entrance to the underworld and ensures that those who lived righteously according 
to the laws of Ma'at get a chance to enter the netherworld and to be resurrected. In 'the miracle of the saving of the mariners', Saint Nicholas has the power to save the mariners from being devoured by monsters in the underworld, as represented by the sea, under the condition that they will become devout Christians and turn themselves to the light of God (instead of the Egyptian Sun god Ra). Ra was believed to annually bring the Egyptians into the light of consciousness by travelling in a solar boat through the sky. His main task was to ensure that at dawn demons would not devour all light so that the sun would never shine again. Together with Orisis, the Moon-god of the dead and the darkness at night, Ra ensured the next sunset every day of the year. Ra's mythical journey may be interpreted as a person's engagement with the unconscious, experiencing the power of demons (representing life's twists), in trying to make life meaningful (Cavalli 2016:57-58, 65-69). In similar vein, Saint Nicholas, as God's intercessor, may be seen as stimulating the sailors to become independent of him and his wonders, to find the light of consciousness in themselves as a source of meaning, and protection against the powers of darkness by converting to Christianity. A comparative religious perspective makes it plausible that Saint Nicholas was different enough, but also overlapped with the pagan gods and goddesses that the grain merchants used to venerate.

\section{Parallels between the Isis-Serapis cult and the Saint Nicholas feast: More than just coincidence?}

This article argues for a historical connection between the grain traders from late antique Alexandria and the companions of Saint Nicholas in the contemporary Dutch feast. To test the validity of this proposition, one should be able to demonstrate how these seamen from Alexandria became part of a feast in a small West European country. The most logical course would be to establish the role these grain traders could have played in the spread of their Isis-Serapis cult and of early Christian belief. As mentioned by Auffarth (2014:26-30), the grain traders were pre-eminently the people who, through their profession, transported religious ideas from place to place and so influenced local religions. In this section, the focus falls on the possible influence exerted by the Isis-Serapis cult on the Saint Nicholas cult in Myra, subsequently in Bari and, still later, in Amsterdam.

The goddess Isis and the god Serapis were both important in Alexandria for their protective powers during storms and their ability to guide the sailors at sea. In Alexandria there were various Isis temples, although the main Isis cult centre was located in Philae near the First Cataract of the Nile. On the island of Philae, each year between the $26^{\text {th }}$ of November and the $26^{\text {th }}$ of December when the Nile inundation had ended and the cool season started, the Egyptian priests organized a 
festival during this so-called month of Choiak. Among other Choiak festival ceremonies, they brought offerings to the goddess Isis and her image was carried across the Nile on a boat. This ceremony was meant to enable Isis to bury her brother-husband Osiris and to resurrect him eight days later in the hope that he would bring them a good new harvest of corn. The temple of Isis was only destroyed in the mid-sixth century during the reign of Justinian, ending 2,000 years of veneration of this goddess in Southern Egypt (Dijkstra and Fokke 2005:73-74, Hahn 2008:203). By that time, however, the cult of Isis had spread over the world and the inhabitants of places as far as Paris and London also venerated this Egyptian-Kushite goddess, ${ }^{9}$ which may be related to the distribution of grain and other commodities from or via Egypt. It is consequently more than likely that the Egyptian grain traders brought their Isis-Serapis cult with them to Myra.

After Bishop Nicholas' sainthood in the sixth century, the city of Myra became a pilgrimage centre and was frequently visited by pilgrims on their way to Jerusalem. It may be safely assumed that the Christians among the grain sailors and merchants continued to spread miracle stories about the saint wherever they went. Consequently, Saint Nicholas became increasingly popular in Byzantine cities in southern Europe such as Venice and Bari. The saint's formal canonization in the tenth century increased the importance of Myra as a pilgrimage site where pilgrims came to buy the oil (myron) that allegedly contained the sweetly scented manna that had kept coming out of the saint's bones. Pilgrims believed in the healing powers of this manna in the same way the Egyptians had believed in the healing water that flowed from the corpse of Osiris (Blackman 1912:70-71).

In $1087 \mathrm{CE}$, a group of 62 seamen and two priests from diverse background and different social classes from Bari and other places, got the assignment from the Barese church officials to transfer the relics of Saint Nicholas from Myra to Bari (Spagnoletti 1986:119-120). The officials gave as a reason that the saint's remains should be kept from the Islamic Seljuk Turks who had attacked Myra and left the city in ruins. The fact that the translation went down in history as the futa sacra ('holy theft') suggests that other than mere religious motives also played a role. Not only did they believe that Saint Nicholas' relics could protect them and the seamen who lived in Bari as Apulian trade routes expanded, but they also hoped that turning Bari into a pilgrimage site would bring economic benefits. Grain traders thus played a significant part in the spread of the Saint Nicholas cult to the West, as is apparent from the writing of Nicephorus, a Barese clerk who mentioned that the translation was carried out by men of Bari on their way to Antioch with

9 Griffiths 1964:67-71, Taylor \& Collingwood 1922:240-287, 283. 
their ships laden with grain and other merchandise (Jones 1988:176-193). ${ }^{10}$ In Bari, Saint Nicholas was venerated especially by seamen, of whom most lived in the old city (Bari Vecchia) (Perotti 1908:239-250).

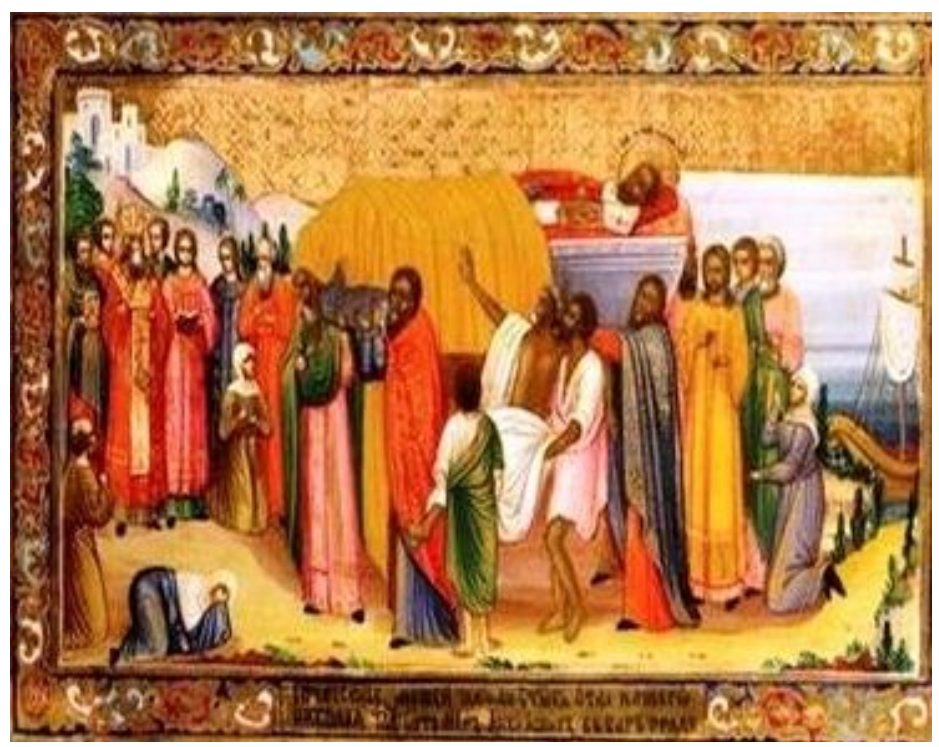

Fig. 7: The transfer or translation of the relics of Saint Nicholas from Myra to Bari. Private collection. Russian icon, nineteenth century. Source: Ikonengalerie Mönius, Regensburg.

Barese religious devotion to Saint Nicholas is ongoing to this day: in commemoration of the translation, the Saint Nicholas festival is still celebrated each year on the $9^{\text {th }}$ of May (Martin 1993:439, Hayes 2016:506-507). During this festival, a larger-than-life, colourful Saint Nicholas statue from the basilica is carried in a procession and set next to the altar for a two-hour mass. The statue then embarks on a day-long sea voyage accompanied by dozens of boats - see Fig. 8 below (Burnett 2009:Chapters 3-4).

10 Hayes 2016:503 mentions that most of the men involved in the translation were sea merchants (nauclerii); see Fig. 7. 


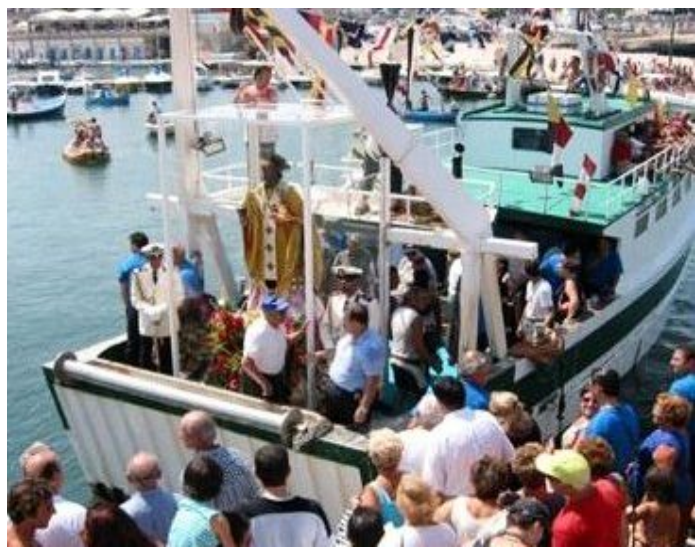

Fig. 8: The commemoration of the translation of Saint Nicholas' relics in Bari. https://www.ilikepuglia.it/notizie/cultura-espettacoli/bari/24/04/2015/bari-il-programmadella-festa-di-san-nicola-2015.html
The translation of the Saint's relics was significant for the further spread of the Saint Nicholas cult in both the Roman Catholic and the Greek Orthodox traditions (Garipzanov 2010:229-230). In the United Provinces of the Low Countries, the cult became significant in the $12^{\text {th }}$ and $13^{\text {th }}$ centuries, with many Saint Nicholas churches being built around the South Sea (Zuiderzee) and in cities near rivers, such as Groningen, Dordrecht, Leiden, Delft and Utrecht (De Groot 2018:21-22). Dutch children placed their shoes near the chimney or inside one of these Saint Nicholas churches to receive candy or coins, such as was recorded in 1427 for the twelfth-century-old Nicolaï church in Utrecht, built at the junction of two waterways (Euwijk and Rensen 2017:4). In Amsterdam, Saint Nicholas became the city's patron saint in the fourteenth century; the oldest of its five Saint Nicholas churches, the Old Church, was built in 1306. The saint's nickname was 'the water saint' ('waterheilige') since he was venerated to protect seamen and others against the dangers of the rivers and the sea.

The popularity of the saint grew from the late $15^{\text {th }}$ until the $16^{\text {th }}$ centuries, when the Dutch became increasingly involved in the grain trade with the Baltic states and the Spanish empire. In Amsterdam, for instance, Saint Nicholas was venerated each year on Sacraments Day. On this day, the citizens of Amsterdam held a miracle procession (see Fig. 9) in honour of their patron saint, comparable to the Saint Nicholas celebration in Bari, thereby passing the city's many Saint Nicholas churches to receive blessings for a safe journey for the ships at the IJ-lake. ${ }^{11}$

From the 1580s, Amsterdam was no longer just a staple food city of regional significance, but became the commercial and financial center of Europe

11 Mak [1995] 2001:43-44 on the observations of Walich Sywaerts, a citizen of Amsterdam. 
with established trade relations with the Spanish empire. The Dutch bought grain in the Baltic states and sold it in Amsterdam but also in many Italian cities belonging to the Spanish empire such as Venice, Genoa and Florence. In these cities and those in Spain (e.g. Seville), Dutch merchants filled their ships with spices from Asia and Africa and sugar from the Spanish Americas to be shipped back to Amsterdam (Engels 1997:47-50). Since 1480, each year on the $5^{\text {th }}$ of December so-called Sint Nicolaescoecks - cookies made of flour with spices and sugar - were sold at the Sinter Niclaesmarckt, held at Dam square in the centre of Amsterdam (De Groot 2018:20-22, 210). Most likely, this is the main reason why in the popular culture and imagination of the Dutch, Saint Nicholas is also identified with a cookie (speculaas), and known as the orange and sugar loving bishop from Spain, the orange-producing country the empire of which the Netherlands until 1588 formed part. At the time, the Damrak - the part of the Amstel river between the Dam and the IJ-lake - was full of ships and the city was frequented by sailors singing impish Saint Nicholas songs that referred to his function as a marriage broker (hylickmaker).

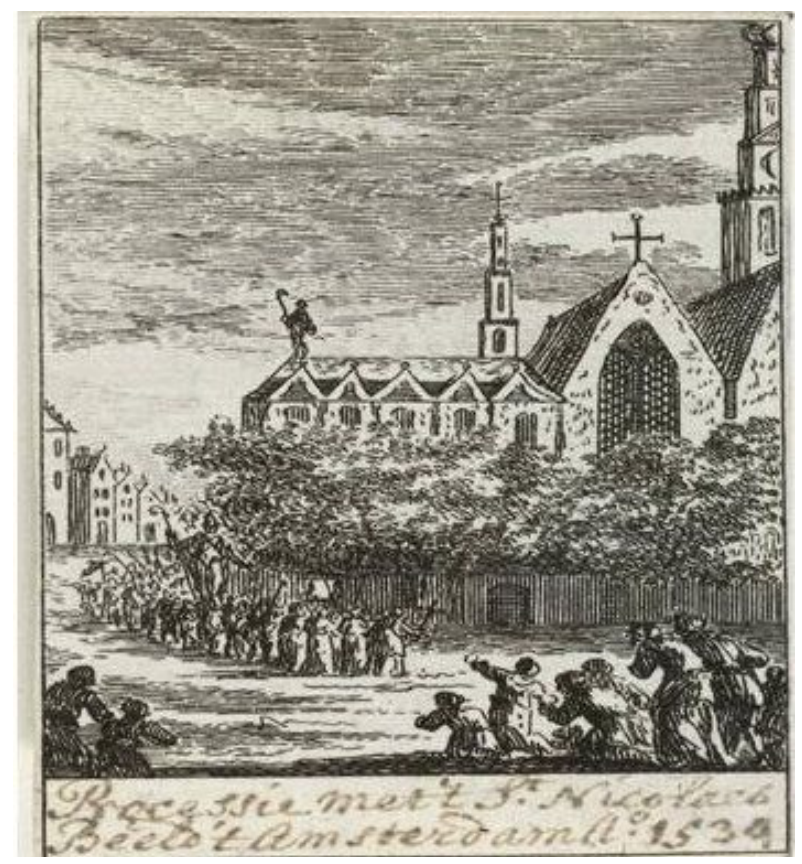

Fig. 9: Procession with the Saint Nicholas image in Amsterdam, 1534. Source: Rijksmuseum, Object nr. RP-P-OB-78.477. 
So once again, a link can be shown between international grain trade and the beloved Saint Nicholas who in Amsterdam was hailed for his sweet cookies and the enhancement of the youth's fertility. This recurring link makes it plausible that Saint Nicholas' companions may be traced back to the socio-religious history of the saint since late antiquity.

\section{Conclusion}

This article argues that North African seamen and grain merchants plausibly played a significant role in the life of Bishop Nicholas of Myra, the historical figure behind Sinterklaas/Santa Claus, who lived during the fourth century CE. These are the semi-historical origins of the saint's companion(s) to have survived into contemporary legend in the Netherlands. The argument stands in contrast to recent views that the saint's helpers were originally non-human, mythical beings, or that they have always presented negative stereotypical images of ethnic Africans. It also argues against the view of Saint Nicholas' companion(s) as the invention of the $19^{\text {th }}$ century Dutch schoolmaster Jan Schenkman, even though the saint's companion(s) were indeed portrayed as ethnic Africans. The article presents evidence that makes it plausible that the saint's companions are originally figures involved in the intercontinental grain trade between North Africa and maritime centres of late antiquity along the Mediterranean coast.

The derogatory blackface images of the Black Peters and their concomitant broken language, which have been part of the Dutch Saint Nicholas feast since at least the nineteenth century, have been experienced by persons of African descent in the Netherlands as painful and discriminatory, even though the origin of the saint's companion(s) pre-dates the Dutch slavery and slave trade. The visual development of the companions is connected to a later stage in history when racial hierarchies were dominant and racist images of black Africans were generally accepted in the Global North. In contemporary Netherlands the depiction of the Black Peters as blackfaced whites is naturally problematic, but instead of the obliteration, many voices are raised, especially in urban areas, in favour of a makeover of the Black Peters' image. The Saint Nicholas feast may also reflect, the argument goes, the multiracial nature of current Dutch society while preserving the cultural memory of a multiracial past. As such, the saint's beleaguered companions are part of the painful history of the emancipation of the black African community in the Netherlands, and debates around their nature and origin should be seen as part of the struggle of the black diaspora community against racism and discrimination and for equal rights in the Dutch labour and housing markets. 


\section{BIBLIOGRAPHY}

Akyürek, T E 2016. Andriake: The port of Myra in late antiquity. In Magdalino, P \& Necipoglu, N (eds.), Trade in Byzantium. Sevgi Gönül Byzantine Studies Symposium. Istanbul: Koç University Research Centre for Anatolian Civilizations, 465-487.

Anrich, G 1917. Der Heilige Nikolaos: Texte und Untersuchungen, II. Leibzig/ Berlin: Teubner.

Archimandrite, M 2014. Trans. J Quinn \& B Sewell. Life, work and miracles of Nikolaos, bishop of Myra (Vitae Nicolai Myrensis per Michaëlem). Michigan: Hope College.

Auffarth, C 2014. With the grain came the gods from the Orient to Rome: The example of Serapis and some systematic reflections. In Wick, P \& Rabens, V (eds.), Religions and trade: Religious formations, trans-formations and cross-cultural exchange between East and West. Leiden: Brill, 19-41.

Babbitt, F C (trans.) [1936] 2003. Plutarch Moralia 5, LCL 306. Cambridge, Mass: Harvard University Press

Blackman, A M 1912. The significance of incense and libations in funerary and temple ritual. Zeitschrift für Ägyptische Sprache und Altertumskunde 50.12:69-75.

Blom, A 1998. Nicolaas van Myra en zijn tijd. Hilversum: Uitgeverij Verloren.

Bock, E W 1972. The transformation of religious symbols: A case study of St Nicholas. Social Compass 19.4:537-548.

Brody, A J 2008. The specialized religions of ancient Mediterranean seafarers. Religion Compass 2.4:444-454.

Budge, E A W 1967. The Egyptian book of the dead: (The papyrus of Ani) Egyptian text transliteration and translation. New York: Dover Publications.

Burnett, S 2009. The cult of St Nicholas in medieval Italy. PhD thesis, University of Warwick.

Butler, B 2007. Return to Alexandria: An ethnography of cultural heritage revivalism and museum memory. California: Left Coast Press.

Carlà-Uhink, F 2017. Caput Mundi: Rome as center in Roman representation and construction of space. AncSoc. 47:119-157.

Cavalli, T F 2016. The alchemical Osiris: From Ra to radium. Psychological Perspectives: A Quarterly Journal of Jungian Thought 59.1:47-70.

Cockrell, D 1997. Demons of disorder: Early blackface minstrels and their world. Cambridge: Cambridge University Press.

De Groot, A D 2018. Saint Nicholas: A psychological study of history and myth. The Hague/ Paris: Mouton \& Co. 
Dijkstra, J \& Fokke, H 2005. Religious encounters on the southern Egyptian frontier in late antiquity, $A D$ 298-642. Groningen: University of Groningen Press.

Dzino, D \& Parry, K 2014. Byzantium, its neighbours and its cultures. Leiden: Brill.

Engels, M-C 1997. Merchants, interlopers, seamen and corsairs: The 'Flemish' community in Livorno and Genoa (1615-1635). Hilversum: Uitgeverij Verloren.

Euwijk, J \& Rensen, F 2017. De identiteitscrisis van Zwarte Piet. Amsterdam: Atlas Contact.

Foss, C 2002. Pilgrimage in medieval Asia Minor. Dumbarton Oaks Papers 56: $129-151$.

Garipzanov, I H 2010. The cult of Saint Nicholas in the Early Christian north (c. 1000-1150). Scandinavian Journal of History 35.3:229-246.

Griffiths, J G 1964. Isis in Oxford. Chronique d'Egypte 39.77-78:67-71. 1970. Plutarch's de Iside et Osiride. Swansea: University of Wales Press.

1980. The origins of Osiris and his cult. Leiden: Brill.

Haas, C 2006. Alexandria in late antiquity: Topography and social conflict. Baltimore, Maryland: Johns Hopkins University Press.

Hahn, J 2008. Die Zerstörung der Kulte von Philae. Geschichte und Legende am ersten Nilkatarakt. In Hahn, J, Emmel, S \& Gotter, U, From temple to church: Destruction and renewal of local cultic topography in late antiquity, 203-242. Leiden: Brill.

Hani, J 1976. La Religion Egyptienne dans la Pensée de Plutarque. Paris: Les Belles Lettres.

Harrison, R M 1963. Churches and chapels of central Lycia. Anatolian Studies 13: $117-151$.

Hayes, D M 2016. The cult of Saint Nicholas of Myra in Norman Bari, c. 1071-c. 1111. The Journal of Ecclesiastical History 67.3:492-512.

Hordon, P \& Purcel, N 2000. The corrupting sea: A study of Mediterranean history. Oxford: Blackwell.

Johnson, S E 1958. Early Christianity in Asia Minor. JBL 77.1:1-17.

Jones, C W 1988. Saint Nicholas of Myra, Bari and Manhattan: Biography of a legend. Chicago: University of Chicago Press.

Keay, S \& Boetto G 2010. Portus and the Alexandrian grain trade revisited. Bollettino di Archeologia 1.330:11-23.

Kilburn, K (trans.) 1959. Lucian VI. LCL 430. Cambridge, Mass: Harvard University Press.

Leidwanger, J 2007. Two late Roman wrecks from southern Cyprus. International Journal of Nautical Archaeology 36.2:308-316. 
Magie, D 1953. Egyptian deities in Asia Minor in inscriptions and on coins. AJA 57.3:163-187.

Mak, G 2001. Amsterdam: A brief life of the city. Amsterdam: Vintage Publishing. Martin, J-M 1993. La Pouille du VIe au XII Siècle. Rome: Ecole Française.

Müller, L F. Piet was waarschijnlijk een gelijkwaardige partner van Sinterklaas. De Volkskrant 22 October 2013, Amsterdam.

Parry, K 2014. Egypt in the Byzantine imagination: Cultural memory and historiography, fourth to ninth centuries. In Dzino, D \& Parry, K Byzantium, its neighbours and its cultures, 181-209. Leiden: Brill.

Perotti, A 1908. Bari Ignota. Trani: Vecchi.

Plutarch, 2003. Moralia, vol. 5, Isis and Osiris. Trans. Babbitt, F C, [first published 1936, orig. 100 CE]. Loeb Classical Library 306. Cambridge, Mass: Harvard University Press.

Ruffini, G 2018. Late antiquity. In Grajetzki, W \& Wendrich, W (eds.), UCLA Encyclopedia of Egyptology, 1-12. Los Angeles: University of California Press.

Quinn, J \& Sewell, B 2014. St. Nicholas of Myra, Life by Michael the Archimandrite (Vita per Michaelem). Brussels: Société des Bollandistes.

Scheer, A-J 2014. Zwarte Sinterklazen: Over Pieten en ander heidens volk. Breda: Papieren Tijger.

Schenkman, J 1850. Sint Nikolaas en zijn knecht. Amsterdam, Gerardus Theodorus Bom.

1907. Sint Nikolaas en zijn knecht. Amsterdam: J Vlieger.

Spagnoletti, M 1986. La traslazione di San Nicola di Mira e la storiografia Barese. Archivio Storico Pugliese 39:101-132.

Taylor, M V \& Collingwood, R G 1922. Roman Britain in 1923. JRS 12:240-287.

Tomorad, M 2005. Egyptian cults of Isis and Serapis in Roman fleets. Water in ancient Egypt. In Amenta, A, Luiselli, M M \& Sordi, M N (eds.), L'Acqua nell'antico Egitto: Vita, rigenerazione, incantesimo, medicamento, 241-253. Rome: L'Erma di Bretschneider.

Vidman, L 2011. Sylloge Inscriptionum Religionis Isiacae et Sarapiacae. Berlin: De Gruyter.

Wade, J 2014. Sailors, merchants and the maritime cults that sailed into the ports (and streets) of Early Byzantium. In Dzino, D \& Parry, K Byzantium, its neighbours and its cultures, 269-287. Leiden: Brill.

Wick, P \& Rabens, V (eds.), Religions and trade: Religious formations, transformations and cross-cultural exchange between East and West. Leiden: Brill.

Wilkinson, J 1981. Egeria's travels to the Holy Land. Jerusalem: Ariel Publishing House. 
Witt, R E 1971. Isis in the ancient world. New York: Johns Hopkins University Press.

Young, G K 2003. Rome's eastern trade: International commerce and imperial policy 31BC-305AD. London: Routledge.

\section{Internet publications}

Gregory of Nazianzus. Oration 43: Funeral oration on the great S. Basil, bishop of Cæsarea. Online available:

https://www.newadvent.org/fathers/310243.htm [21 January 2021].

Helsloot, J 2011. De oudst bekende naam van Zwarte Piet. Digital Newsletter, Meertens Instituut. Online available:

https://www.meertens.knaw.nl/cms/nl/cms/nl/109-nieuwsbrief/uitgelicht/ 143677-de-oudst-bekende-naam-van-zwarte-piet-pieter-me-knecht-141850 [21 January 2021].

NOS Nieuws 2013. Nederland moet stoppen met vieren van Sinterklaas. Online available: http://nos.nl/video/565674-nederland-moet-stoppen-met-vierenvan-sinterklaas.html. [22 October 2013].

Putseys, J 2015. Is onze Zwarte Piet racistisch?

Online available: EOS http://eoswetenschap.eu/artikel/onze-zwarte-pietracistisch. [6 October 2015]. 